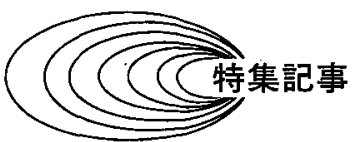

\title{
建築音響と環境騒音制御における音場の可視化*
}

\author{
坂本 慎一**, 佐藤 史明 $* * *$, 矢野 博夫****, 橘 秀樹****
}

\section{Visualization of sound fields for architectural acoustics and environmental noise control}

\author{
Shinichi Sakamoto, Fumiaki Satoh, Hiroo Yano and Hideki Tachibana
}

1.はじめに

音は情報や情緒を伝えるための最も有効な手段であり， その品質の良し悪しは実際に音を「聴（聞）く」，すな わち可聴化によって判断される。建築音響の分野では， 室内外の音環境の評価のためには可聴化技術が不可欠で ある。一方，品質の高い音環境を創造する，いわ音 響計画・音響設計の途中段階では，可聴化とともに可視 化が大きな役割を果たす。すなおち，音場における音の 挙動を可視化することによって，その発生や伝搬のメカ ニズムを直感的に把握でき，騷音対策の立案や音響設計 にフィードバックすることができる，著者らは，音場の 可視化技術を様々な音響設計や騒音対策を支援する有効 な技術として捉えている。本稿では，我々がこれまでに 行った音場の可視化の事例を紹介し，建築音響および騒 音制御分野における応用例について述べる.

\section{2. 音響インテンシティ法による可視化}

音響インテンシティは，一般的な音の計測量である音 圧とは異なり，音のエネルギーの流れを意味する。音響 インテンシティは以下の(1)式のように定義されている.

$$
I=\frac{1}{T} \int_{0}^{T} p(t) u(t) d t
$$

ただし， $p(t)$ : 音圧, $u(t)$ : 粒子速度.

(1)式に示されるように，音響インテンシティを测定す るためには音圧と粒子速度を同時に計測する必要がある。 粒子速度は直接測定することが難しいため, 近接する 2 点の音圧の差分を基に近似的に求める力法がとられるこ とが多い、音響インテンシティ計測では，音の強さと方 向が同時に得られるため, 多点で計測した結果をべクト ル図として図示すれば筀間的な音響エネルギーの流れを 視賞的に確認することができる。

\footnotetext{
* 原稿受付 2006 年 10 月 30 日

** 東京大学生産技術研究所 ( $=153-8505$ 東京都目黒区駒場 4-6-1, E-mail : sakamo@iis.u-tokyo.ac.jp)

*** 千葉工業大学工学部

**** 千葉工業大学情報科学部
}

\section{1 楽器からの音響放射特性の測定例}

Fig. 1 は，チェロからの放射音（第 2 弦を加振）を音 響インテンシティ計測法により計測した結果である1). 基音 $(144 \mathrm{~Hz})$ が含まれる $160 \mathrm{~Hz}$ 帯域では $f$ 字孔を中 心に一様な放射となっているが，第 2 倍音が含まれる $315 \mathrm{~Hz}$ 带域では音が吸い込まれる部分も見られる。こ のように，音響インテンシティ法によれば複雑な音の放 射特性を非常に明解に表現できるので，音響放射・伝搬 メカニズムを理解する際に有効である.

\section{2 空サッシからの透過音の可視化}

建築音響における音響インテンシティ法の応用として， 空サッシからの音響透過を测定した例2)を示す。壁構造 や建具などの遮音性能を示寸音響透過損失の測定は, 通 常 2 つの残響室を用いる方法がとられるが，音響インテ ンシティ法を用いる場合は受音室を無響室とし（Fig. 2
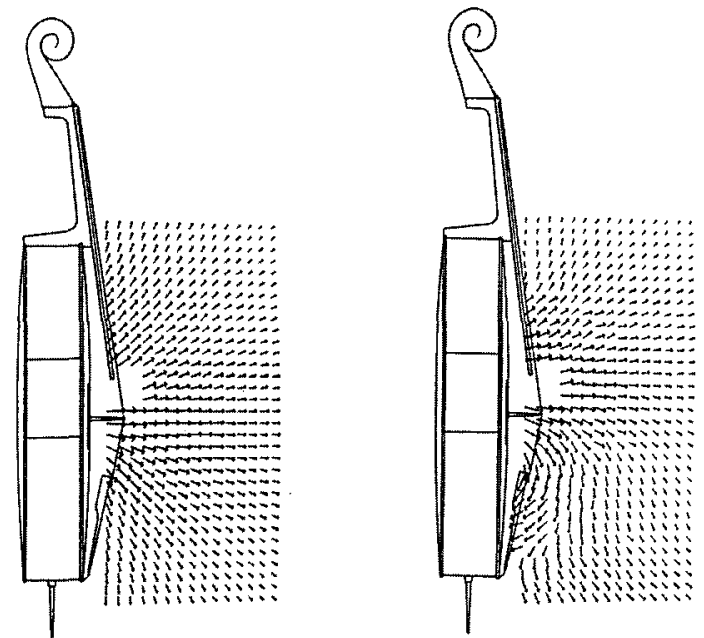

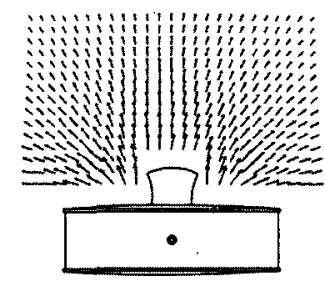

(a) $160 \mathrm{~Hz}$

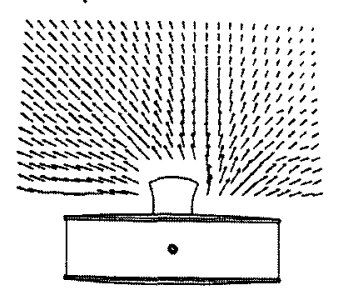

(b) $315 \mathrm{~Hz}$
Fig. 1 Visualization of sound radiation characteristics from a violoncello by sound intensity vector. 
参照)，試料を透過してくる音響パワーを直接測定する. この方法によれば，部位ごとの音響透過の様子を詳細に 把握することができるので，特に壁構造や部材の開発段 階での検討に有効である。Fig. 3 は，試料となる密サッ シからの音響透過の様子を把握するために行った音響仡 ンテンシティの多点計測結果を図示したものである、計 測では，音源室で音源スピーカより広带域ノイズを放射 し，受音室内の測定試料の前面部全体にわたって等間隔 (5 cm 間隔) に設定した 1,554 点の測定点における法

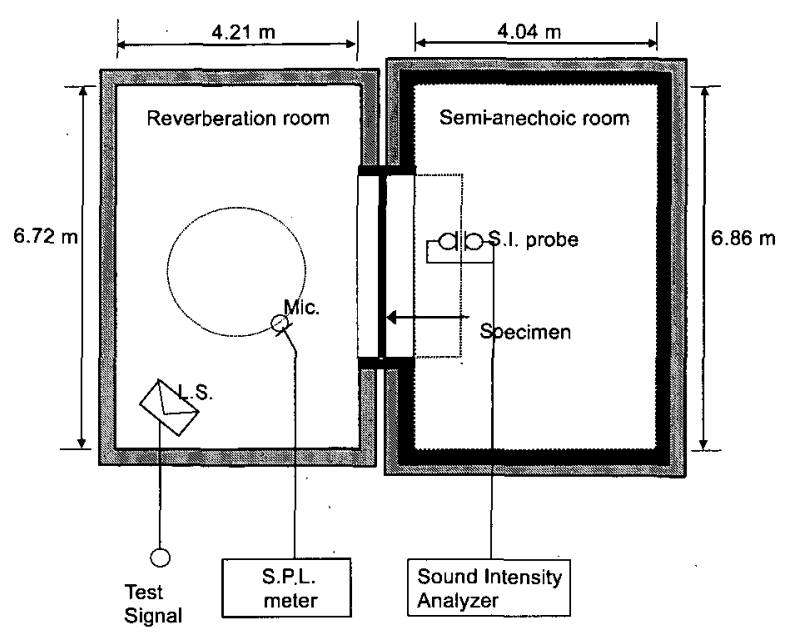

Fig. 2 Measurement set-up for sound transmission through a glass window by SI method.

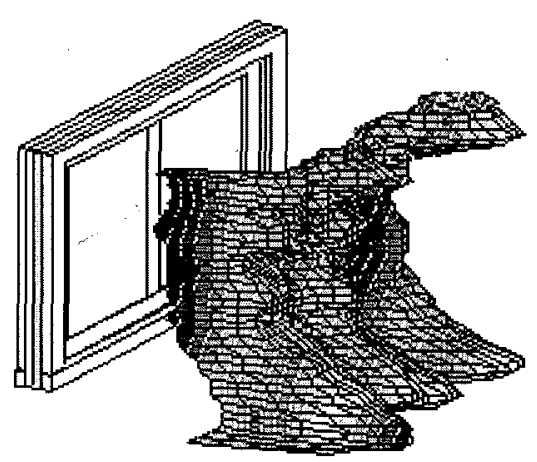

(a) $500 \mathrm{~Hz}$

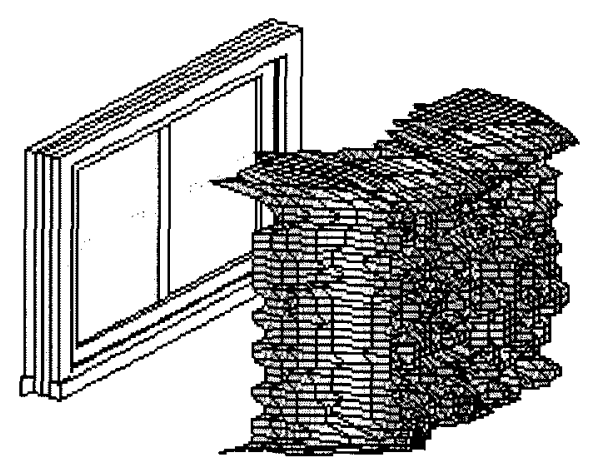

(b) $1.6 \mathrm{kHz}$

Fig. 3 Measurement result of distribution of normal sound intensity from a glass window.
線方向音響インテンシティを测定した，図を見ると， $500 \mathrm{~Hz}$ 帯域(a)ではサッシ下部の隙間部分からの音の透 過が明確に見られているのに対して，1.6 kHz 带域(b) はガラスのコインシデンス周波数を含むため, ガラス面 全体からの音の透過が顕著である。このような実験に よって音響透過性能を詳細に調べ, 得られた結果を遮音 性能向上のための開発研焭にフィードバックすることが できる。

\section{3. 数值解析を用いた室内音場の可視化}

音響数值解析を用いた室内音場予測では，設計図の段 階で空間の幾何形状データと音響特性デー夕を入力する ことによりその空間の音響特性を予測する。したがって， 内装材料や壁面形状の変更などは入力デー夕の部分的な 変更のみで実行できるので，従来技術である縮尺模型実 験等と比べて必要な労力が小さく，試行錯䛊を常とする 設計行為にとっては非常に有效な手法となりうる. 解析 手法として, 近年, 音の波動性を考慮して精密に空閒内 の音の伝搬をシミュレートするいくつかの手法が研究さ れている。人間が感知できる周波数範囲は非常に広いの で, 現時点では音響設計に必要な周波数带域をすべて解 析できるわけではないが, 精度が高く効率のよい手法と して発展が期待されている。著者らは，上に述べた音響 波動数値解析手法のうち，時間領域差分法（FDTD法） と呼ばれる解析方法の適用性について検討を行ってきた。 ここではその手法の概要を述べ，室内音響設計に応用し な例を可視化結果とともに紹介する。

\subsection{FDTD 法}

\section{[1] 基礎関係式}

空気中における 3 次元波動伝搬は以下の才イラーの式, 連続の式で表される。

$$
\begin{aligned}
& \rho \frac{\partial u}{\partial t}+\frac{\partial p}{\partial x}=0 \\
& \rho \frac{\partial v}{\partial t}+\frac{\partial p}{\partial y}=0 \\
& \rho \frac{\partial w}{\partial t}+\frac{\partial p}{\partial z}=0 \\
& \frac{\partial p}{\partial t}+\kappa\left(\frac{\partial u}{\partial x}+\frac{\partial v}{\partial y}+\frac{\partial w}{\partial z}\right)=0
\end{aligned}
$$

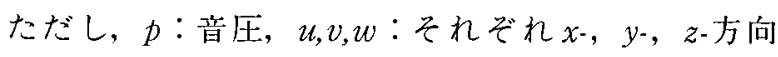
粒子速度を表し, $\rho$ : 空気密度, $x$ : 空気の体積弾性率 である。

对象とする音場をスタッガードグリッド（Fig. 4 参 照）に分割し，式(2)〜(5)式中の微分項を有限差分で近似 する，時間，空間ともに 2 点差分で近似すると，以下の 差分スキームが得られる。

$$
\begin{aligned}
& u^{n+1}\left(i+\frac{1}{2}, j, k\right)=u^{n}\left(i+\frac{1}{2}, j, k\right) \\
& -\frac{\Delta t}{\rho \Delta h}\left\{p^{n+\frac{1}{2}}(i+1, j, k)-p^{n+\frac{1}{2}}(i, j, k)\right\}
\end{aligned}
$$




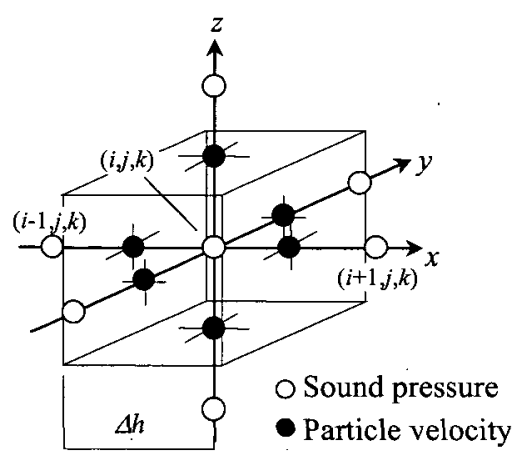

Fig. 4 Staggared grid system for FDTD method.

$$
\begin{aligned}
& v^{n+1}\left(i, j+\frac{1}{2}, k\right)=v^{n}\left(i, j+\frac{1}{2}, k\right) \\
& -\frac{\Delta t}{\rho \Delta h}\left\{p^{n+\frac{1}{2}}(i, j+1, k)-p^{n+\frac{1}{2}}(i, j, k)\right\} \\
& w^{n+1}\left(i, j, k+\frac{1}{2}\right)=w^{n}\left(i, j, k+\frac{1}{2}\right) \\
& -\frac{\Delta t}{\rho \Delta h}\left\{p^{n+\frac{1}{2}}(i, j, k+1)-p^{n+\frac{1}{2}}(i, j, k)\right\} \\
& p^{n+\frac{1}{2}}(i, j, k)=p^{n-\frac{1}{2}}(i, j, k) \\
& -\frac{\varkappa \Delta t}{\Delta h}\left[\left\{u^{n}\left(i+\frac{1}{2}, j, k\right)-u^{n}\left(i-\frac{1}{2}, j, k\right)\right\}\right. \\
& +\left\{v^{n}\left(i, j+\frac{1}{2}, k\right)-v^{n}\left(i, j-\frac{1}{2}, k\right)\right\} \\
& \left.+\left\{w^{n}\left(i, j, k+\frac{1}{2}\right)-w^{n}\left(i, j, k-\frac{1}{2}\right)\right\}\right]
\end{aligned}
$$

初期条件として音源点近傍に適切な初期音圧分布を与 え，(6)（9)式を逐次計算することによって音場の過渡応． 答を計算することができる．著者らの行う音響解析では， 線形システムにおいて重要な物理量であるインパルス応 答をシミュレートするために, 音源の初期条件として次 式で表されるようなパルス状の音圧分布（Fig. 5 参照） を与えている。

$$
p(x, y, z)=\exp \left\{-\frac{\left(x-x_{s}\right)^{2}+\left(y-y_{s}\right)^{2}+\left(z-z_{s}\right)^{2}}{d^{2}}\right\}
$$

壁面に㧍ける境界条件は, 法線方向音響インピーダン スによって規定される．法線方向音響インピーダンス $z_{n}$ は以下のように定義される。

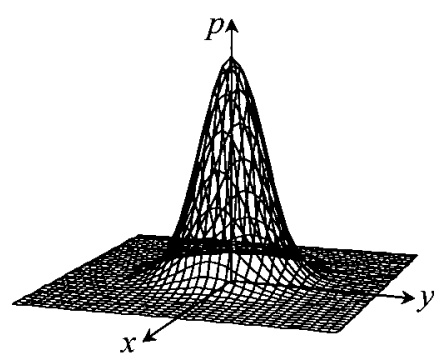

Fig. 5 Spatial distribution of initial condition of sound pressure with Gaussian profile.

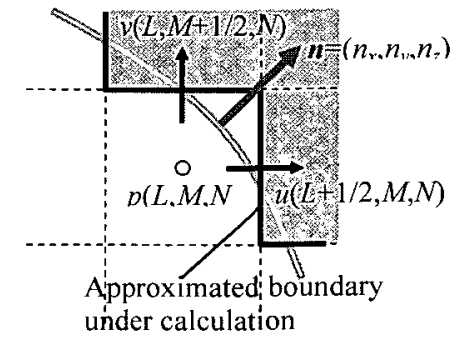

Fig. 6 Definition of sound pressure and particle velocities on the boundary.

$$
z_{n}=p / u_{n}
$$

たな゙し，到は壁面における法線方向粒子速度を表す。

計算に際しては，壁面が定義されたグリッド面上の各 方向粒子速度を, 式(11)に基づいて次式(12)，(13)により計算 する (Fig. 6 参照).

$$
\begin{aligned}
& u^{n+1}\left(L+\frac{1}{2}, M, N\right)=\frac{p^{n+\frac{1}{2}}(L, M, N)}{z_{n}} n_{x} \\
& v^{n+1}\left(L, M+\frac{1}{2}, N\right)=\frac{p^{n+\frac{1}{2}}(L, M, N)}{z_{n}} n_{y}
\end{aligned}
$$

\section{[2]高次差分の適用}

以上に述べたように，通常の FDTD 法では微分方程 式に現れる 1 階微分係数を 2 点差分で近似するが，空間 差分の近似次数を上げて計算精度を高放法も考えら れる ${ }^{3}$. 微分の計算点を中心とした $2 \mathrm{M}(\mathrm{M}=1,2, \cdots)$ 点を参照点とした高次差分を適用すると (Fig. 7 参照), 式(6)（9)にかわって差分スキームは次のようになる。

$$
\begin{aligned}
& u^{n+1}\left(i+\frac{1}{2}, j, k\right)=u^{n}\left(i+\frac{1}{2}, j, k\right) \\
& -\frac{\Delta t}{\rho \Delta h} \sum_{m=0}^{M} C_{m}\left\{p^{n+\frac{1}{2}}(i+m+1, j, k)-p^{n+\frac{1}{2}}(i-m, j, k)\right\} \\
& v^{n+1}\left(i, j+\frac{1}{2}, k\right)=v^{n}\left(i, j+\frac{1}{2}, k\right) \\
& -\frac{\Delta t}{\rho \Delta h} \sum_{m=0}^{M} C_{m}\left\{p^{n+\frac{1}{2}}(i, j+m+1, k)-p^{n+\frac{1}{2}}(i, j-m, k)\right\} \\
& w^{n+1}\left(i, j, k+\frac{1}{2}\right)=w^{n}\left(i, j, k+\frac{1}{2}\right)
\end{aligned}
$$

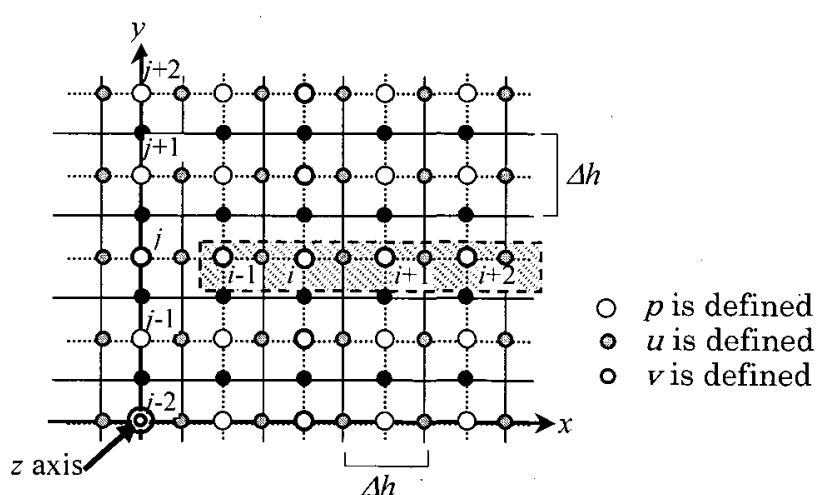

ア゙は $i+1 / 2$ を計算点とした場合の $\mathrm{M}=2$ における差分参 照点の存在範囲を表す。

Fig. 7 Reference points for calculating finite difference. 


$$
\begin{aligned}
& -\frac{\Delta t}{\rho \Delta h} \sum_{m=0}^{M} C_{m}\left\{p^{n+\frac{1}{2}}(i, j, k+m+1)-p^{n+\frac{1}{2}}(i, j, k-m)\right\} \\
& p^{n+\frac{1}{2}}(i, j, k)=p^{n-\frac{1}{2}}(i, j, k) \\
& -\frac{x \Delta t}{\Delta h}\left[\sum _ { m = 0 } ^ { M } C _ { m } \left\{u^{n}\left(i+m+\frac{1}{2}, j, k\right)\right.\right. \\
& \left.-u^{n}\left(i-m-\frac{1}{2}, j, k\right)\right\} \\
& +\sum_{m=0}^{M} C_{m}\left\{v^{n}\left(i, j+m+\frac{1}{2}, k\right)-v^{n}\left(i, j-m-\frac{1}{2}, k\right)\right\} \\
& \left.+\sum_{m=0}^{M} C_{m}\left\{w^{n}\left(i, j, k+m+\frac{1}{2}\right)-w^{n}\left(i, j, k-m-\frac{1}{2}\right)\right\}\right] \\
& \quad C_{m}=D_{m} / \sum_{i=0}^{L}(2 l+1) D_{l} \\
& D_{m}=(-1)^{m+1} \frac{(2 M-1)^{2}(2 M+1)^{2}}{\{2(M-m)+1\}^{2}} \frac{(2 M+1) !}{m !(2 M-m+1) !}
\end{aligned}
$$

\section{2 室形の違いによる音波伝搬性状の差異}

室内音響設計では，室形状の選定が基本的に最も重要 である。ホールや劇場の室形状として典型的な「かた ち」には，直方体 (シューボックスタイプ), 扇形, 楕 円形などがあるが, 室の基本形状が異なると室内の音波 伝搬特性も大きく晎なる。そこで，典型的な室の平面形 として上記 3 形状を設定し, 音源点からパルスを発生し た後の過渡的な音波伝搬をFDTD 法によりシミュレー トし，室形の差異による音響特性の違いについて検討し た例を示す4)。この検討では，平面形状の違いに特に着 目しているため，2次元モデルに対する数值解析を行っ ている．実際のホール・劇場では，室内音場の搪散性を 高めるために壁面形状に比較的細かな山凸（音響拡散 体）が設計されるのが通常である。そこで，Fig. 8 に示 す屏風折れ型の拡散体を周壁に設置した場合の音響効果 の違いについても検討した。

室内における音圧分布の時間变化を計算した結果を Fig. 9 に示市.これらの室は面積を同一 $\left(518.4 \mathrm{~m}^{2}\right)$ と し，周壁の吸音率をすべて 0.2 として条件を合わせてい る。それぞれの室において図中の位置を音源とし，パ ルス放射後 $35 \mathrm{~ms}, 90 \mathrm{~ms} ， 145 \mathrm{~ms} ， 200 \mathrm{~ms}$ 後の瞬時音 圧分布を示している．室形状が左右対称であるので，各 図の左半分に拡散体なしの室内音圧分布を，右半分に拡 散体（Fig. 8 参照）を周壁に設置した場合の室内音圧分 布を表示した．拡散体を設置しない室では強い反射音が 離散的な波頭面として明瞭に現れているが，拡散体を設 置した室では拡散壁の効果によって細かな反射波が多数 発生し, 室内音圧分布が急速に均一化される様子が分か る.

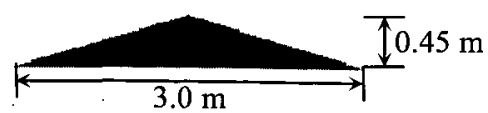

Fig. 8 Sound diffusers attached to the wall under investigation.
壁面拡散の恥感的な効果は，受音点における音の響き の情報によって確認される，そこで，図中○位置のイン パルス応答を計算した。計算結果を Fig. 10 に示す。拡 散体を設置した室では，拡散体なしの場合に見られる離 散的な強い反射音群がなくなり, 応答のエンベロープが 滑らかになっている様子が観察される。これらの計算結 果を可聴化することによって，壁面拡散の効果を耳で確 認することも可能である.

以上に示したように，FDTD法を用いた数值解析に よれば，室内の過渡的な音波伝搬を詳細に調べることが できる。また，インパルス応答を全時間積分すれば，定 常状態における音圧分布特性についても検討することが できるので，室内音響分野における応用範囲は広い。

\subsection{3 次元音場における適用例}

3 次元音場に FDTD 法を適用した例として，小ホー ルの音響特性を解析 ${ }^{5}$ し，過渡音圧分布を可視化した結 果を Fig. 11 に示す。このホールは座席数 300 席弱の小 規模ホールであるが，現在の計算機（WS）性能で上限 周波数 $1 \mathrm{kHz}$ 带域（1 Oct. band）までの解析が可能で ある。図は，○位置に設置した音源からパルスを放射し た後の音圧分布の時間変化を表示したもので，壁面の拡 散処理と後壁の吸音処理によって急速に音場が拡散され る様子が示されている。このホールは曲面を多用した平 面計画であるため，設計当初より音の集中に起因するエ コー障害の発生が眸念された，そのため，基本設計の段 階で 2 次元波動数值解析による検討を行い, 音響的な検 討がなされた事例である。

波動数值解析が实際のホール音場に適用された例はま だ少ない。そのため，この種の解析手法の穾空間への適 用性についてはまだ検討の余地が多く残されている，最 も検討を要すべき課題は，実音場における境界条件の同 定とシミュレーションへの導入手法である。現実の建築 空間の境界条件は吸収，共鳴，振動系との連成等，さま ざまなメカニズムが関与するため，その周波数特性は非 常に複雑となる。このような境界条件を適切にモデル化 し，結果として得られる空間特性の精度を高めるために は, 多くの事例の蓄積が必要であるうと考えている。

\section{4. 波動数值解析の環境騒音予測への応用}

波動音響解析は室内音場だけでなく屋外環境騒音に対 しても適用可能である。著者らは，主に道路交通騒音予 測に対する FDTD 法の適用可能性を検討している ${ }^{6,7)}$. 道路交通騒音は音源を線音源としてモデル化できるため, 道路断面を対象とした 2 次元解析が有效に利用できる。 近年では, 高架・平面併設道路や半地下構造道路等の複 雑な道路構造がしばしば建設されるようになったため, 複雑な場の解析に有効な波動数值解析への期待が高まっ ている。ここでは，音の可視化例として遮音壁による回 折音場を解析した事例について述べる。

Fig. 12 は，種類の典型的な遮音壁形状（值壁(a)，頂 


\section{(a) Rectangular}
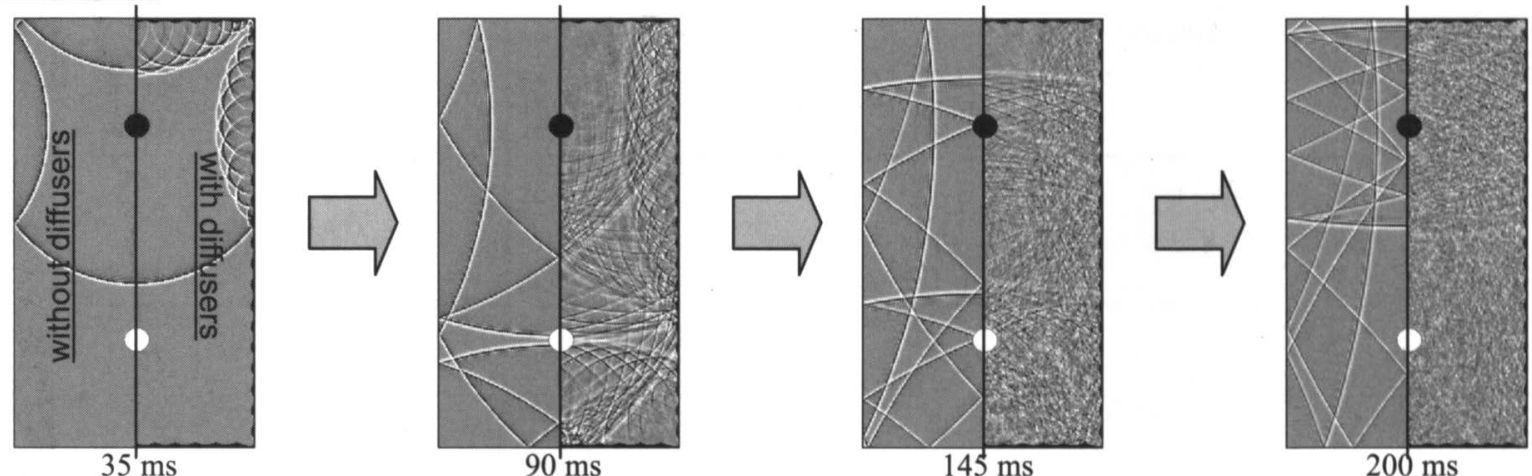

$\underline{90 \mathrm{~ms}}$

$145 \mathrm{~ms}$

$\underline{200 \mathrm{~ms}}$

\section{(b) Fan-shaped}

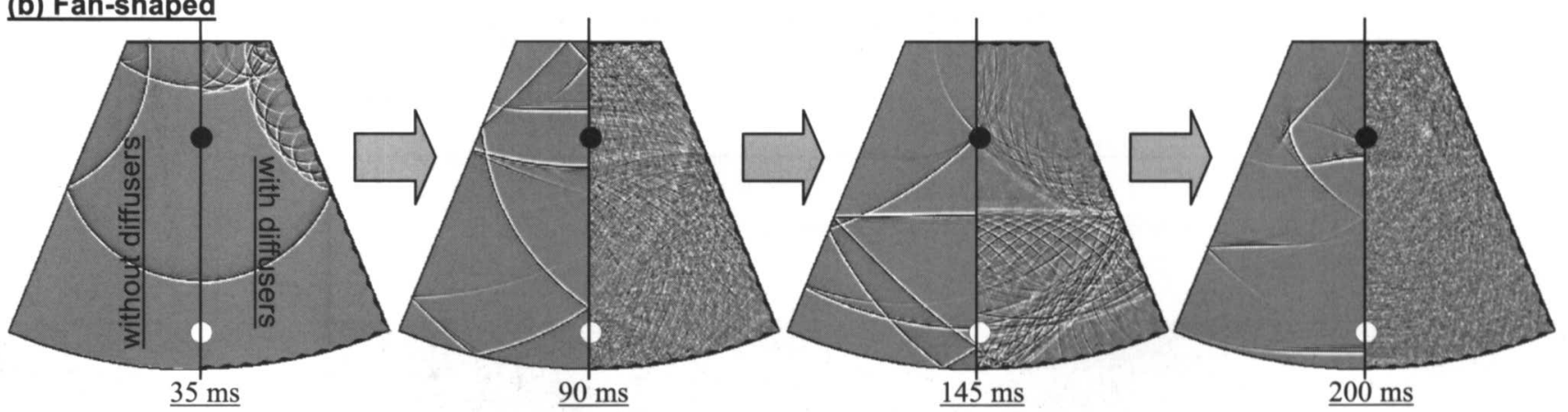

(c) Elliptic
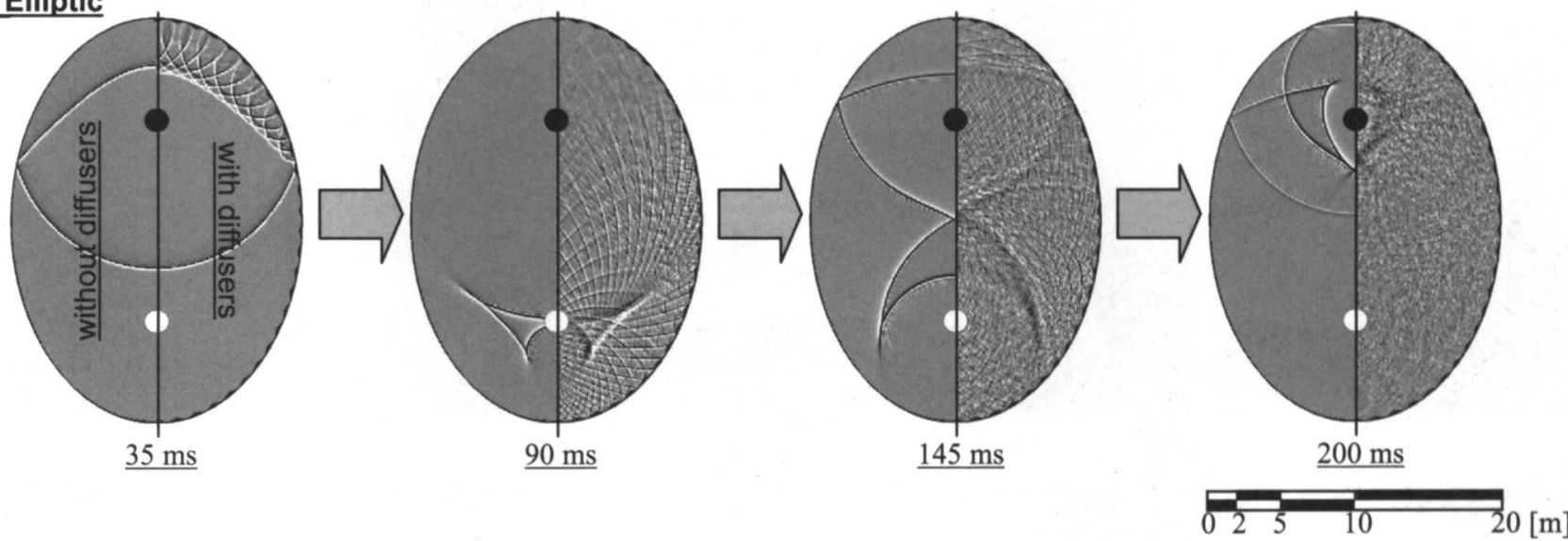

Fig. 9 Sound propagation in a rectangular (a), fan-shaped (b) and elliptic (c) rooms without diffusing treatment (left hand side) and with that (right hand side).

部を円弧型(b)および逆 L 字型(c)に変形させた壁) につ いて音波回折の様子を可視化した例である。音源 S か らパルス発生後, 波面が障壁の頂部に到達すると音波は 回折し，エッジ点を中心とした同心円状に波面が広がる 様子が明瞭に示される。困中, 音の振幅を色の濃淡で表 現しているが，障壁の裹側では回折角が深いほど音波の 振幅が徐々に小さくなる様子が表現されている. 円弧型 (b)および逆 L 字型(c)では壁面と地面での多重反射に伴 う波面の往来が見られ，音場が複雑になっている．この ような可視化によれば, 音源から受音点に至る音波の挙 動を細かく観察することができるので，特に吸音部位の 検討などの騒音対策を検討する際に役立つものと考えら れる。

\section{5.むすび}

本稿では，建築音響および環境騒音予測の分野におけ る音場の可視化について著者らの研究を紹介した。音は, 空気の微小な振動の結果として生じる現象であり, その 振幅は大気圧に対して非常に小さいので, 物理的に直接 これを可視化することは困難である。そこで，計測や音 場解析の手法を用いて音場を可視化する手法が用いられ る。これらの方法を用いれば，波動現象である音の複雑 な挙動を明瞭に表現することができ, 音響設計や騒音対 策の支援技術として有効である。実務的な応用ばかりで なく，音場を可視化する方法は音響に関する教育用の ツールとしても効果的であると考えられ，著者らのグ ループでもいくつかのツールの開発を行っている 
(a) Without diffusing treatment

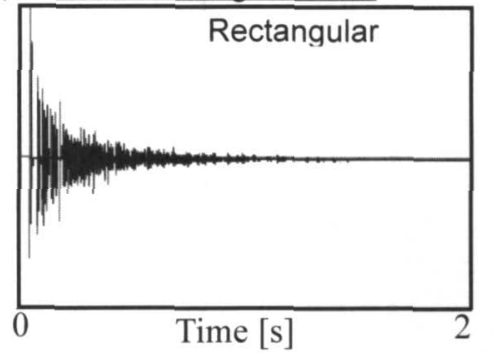

(b) With diffusing treatment
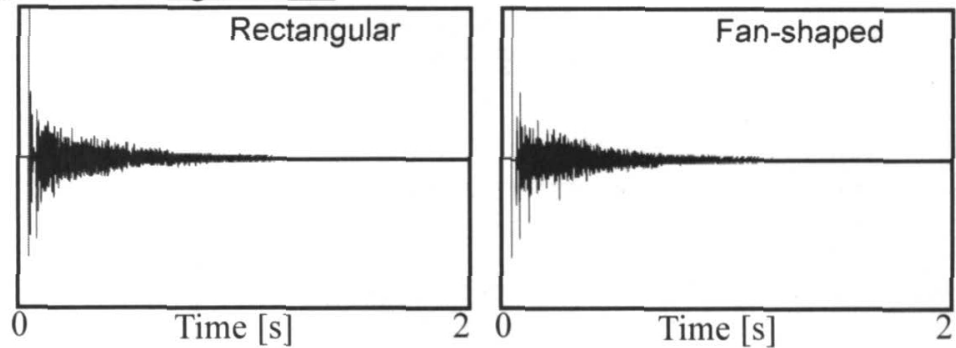

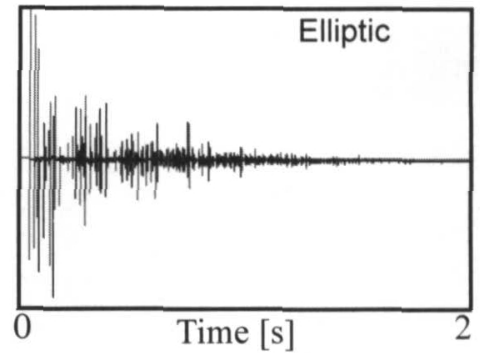

Time $[\mathrm{s}]$

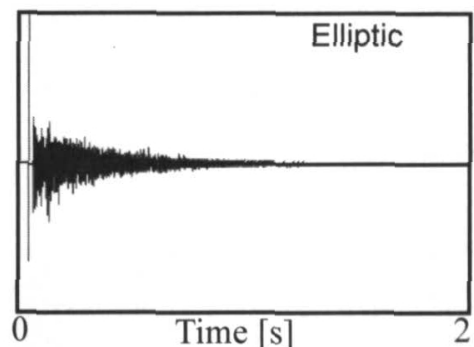

Time $[\mathrm{s}]$

Fig. 10 Calculation results of impulse responses at the receiving points shown in Fig. 9 .

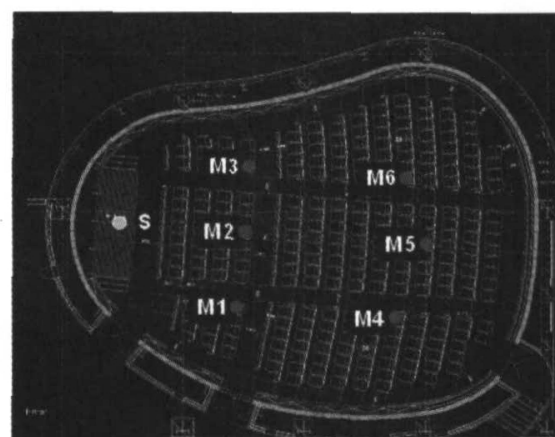

Plan
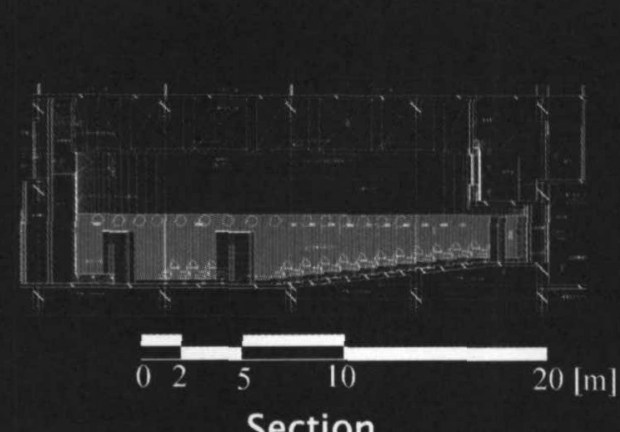

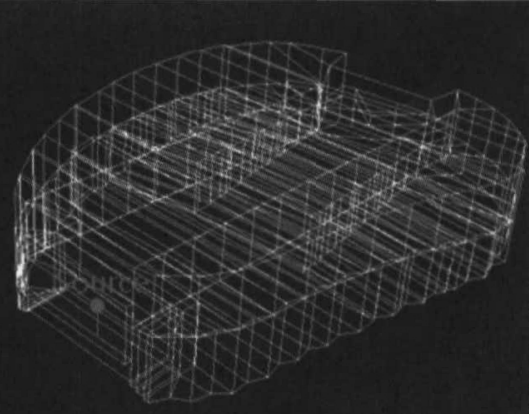

Room shape assumed in the calculation (wire-frame figure)

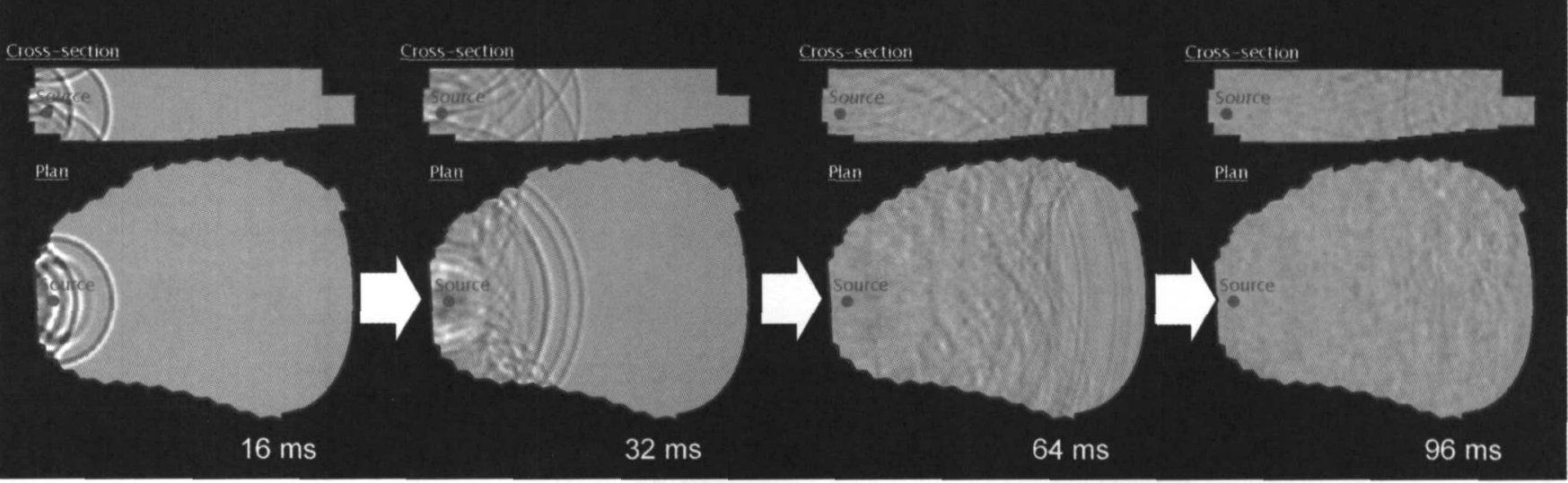

Fig. 11 Sound field simulation on a 3-dimensional room.

\section{参考文献}

1) 㰌 秀樹，日高新人：千ェロの音響放射特性の可視化，日本 音響学会誌, 46 卷 10 号 (1990) pp.864-866.

2 ）須田直子, 佐藤史明, 矢野博夫, 須永明宏, 横田考俊, 坂本 慎一，橘 秀樹：音響インテンシティ法によるサッシの部伦 別遮音性能の把握, 日本騒音制御工学会講演論文集, (2003. 9) pp.109-112.

3 ）坂本慎一，山本航介，橘 秀樹：FDTD 法における多点差分
スキームの安定性解析, 日本音響学会講演論文集, (2004.9) pp.953-954.

4 ) Yokota, T., Sakamoto, S., Tachibana, H. : Visualization of sound propagation and scattering in rooms, Acoustical Science \& Technology, Vol.23, No.1 (2002) pp.40-46.

$5)$ Sakamoto, S., Ushiyama, A., Nagatomo, H. : The FDTD calculation of impulse responses of a hall and their correspondences with measurement results, Proceedings of WESPAC IX 2006 (2006.6) CDROM No.550. 
(a) Straight barrier
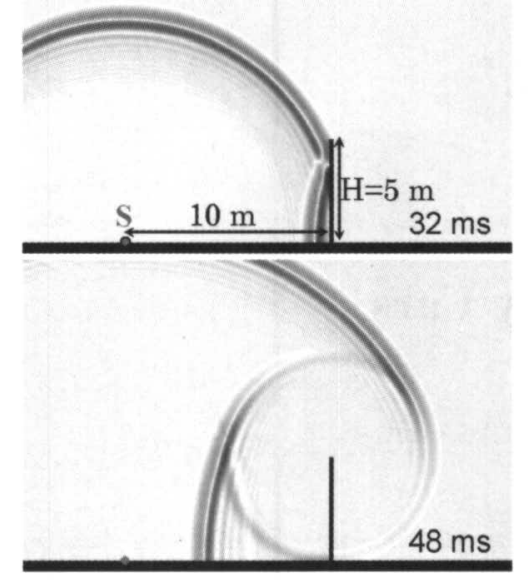

(b) Arc-type barrier
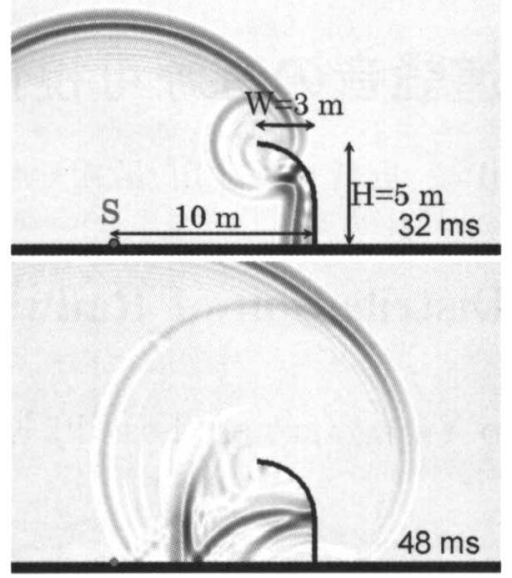

(c) Inverse-L type barrier

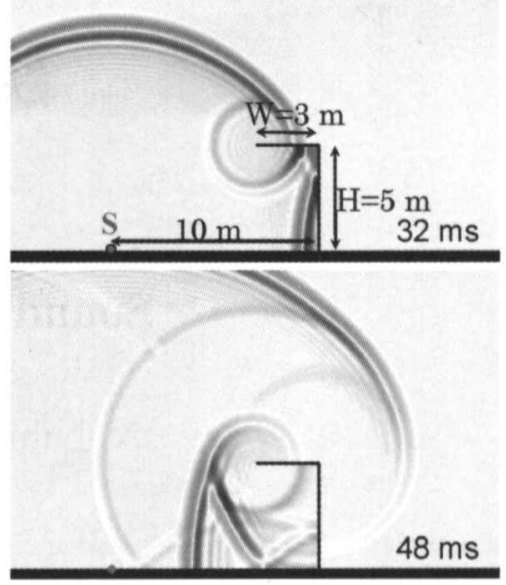

Fig. 12 Sound diffraction over various types of noise barriers.

6 ) Sakamoto, S., Hirano, J., Satoh, F., Tachibana, H., Funahashi, O., Mori, T. : Experiment and calculation of sound radiation characteristics from semi-underground road, Proceedings of Inter-Noise 2005 (2005.8) CDROM, No. 1815.

7 ) Sakamoto, S., Tachibana, H. : Numerical analysis on noise attenuation performance of embankment, Proceedings of
Inter-Noise 2003 (2003.8) CDROM N 918.

8 ) Sakamoto, S., Ueno, K., Tachibana, H. : Visualization of resonance phenomena for acoustic education, Proceedings of 18th ICA (2004.4) III-2311-2312.

9) Tachibana, H., Sakamoto, S., Ueno, K. : Visual and aural demonstration for architectural acoustics Proceedings of 18th ICA (2004.4) III-2317-2318. 


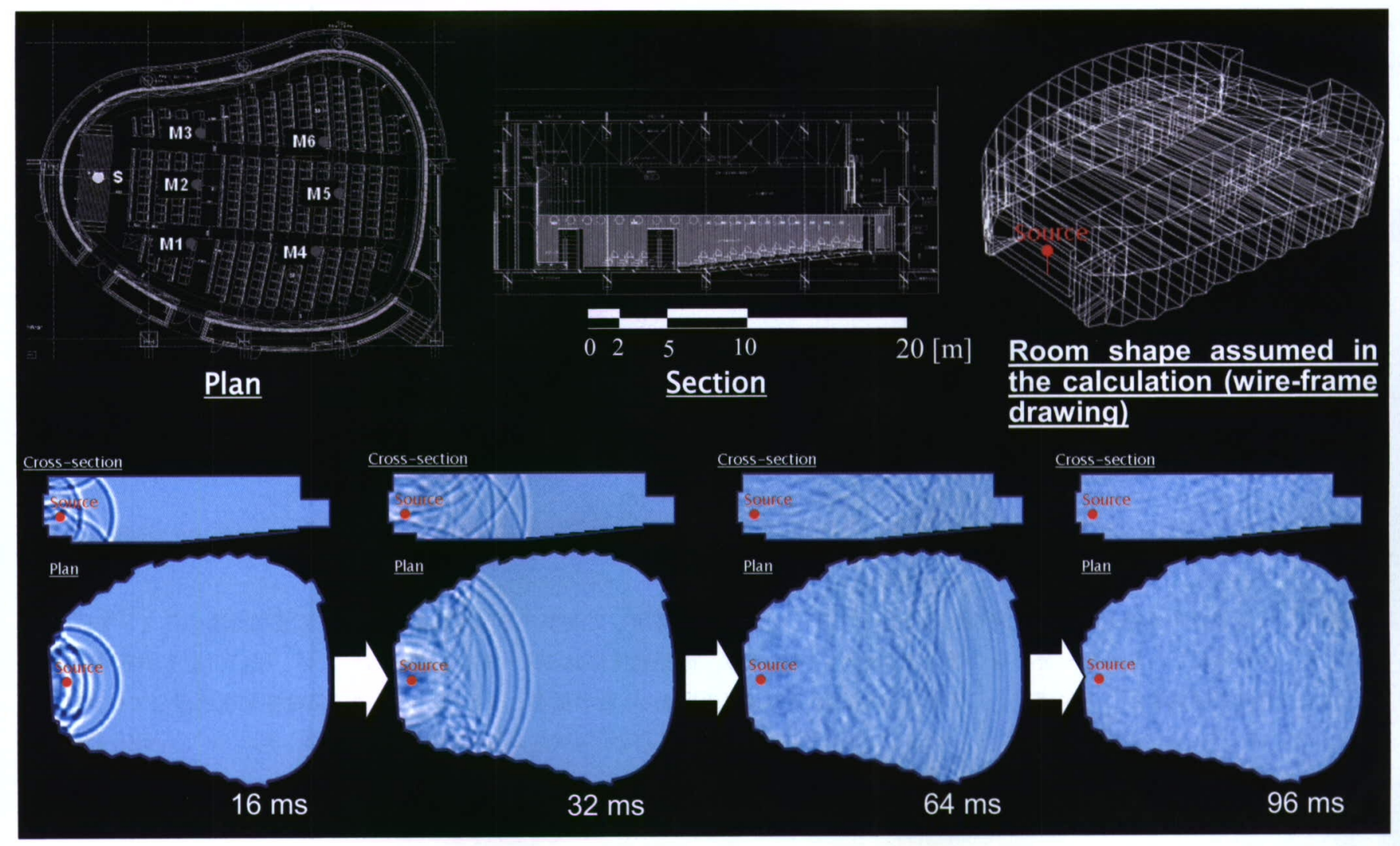

口絵 5 ホールにおける音響伝搬を FDTD 法によって計算し，可視化した例. 音源点（○）から発生したパルス音が時間とともに 空間内に広がる様子が観察できる. このような計算結果をアニメーション表示することによってビジュアルに表現すると， 室の音響伝搬特性を感覚的に捉えることができる.

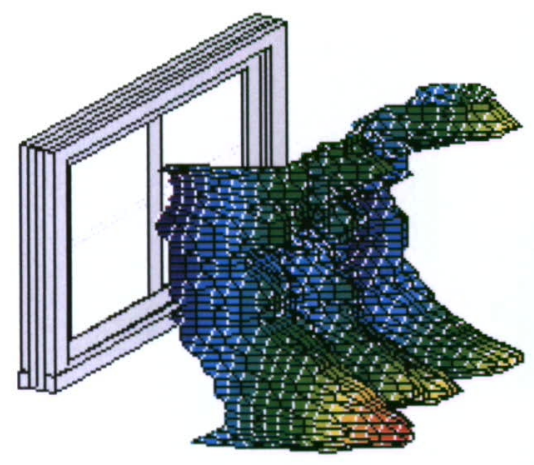

$500 \mathrm{~Hz}$ 帯域

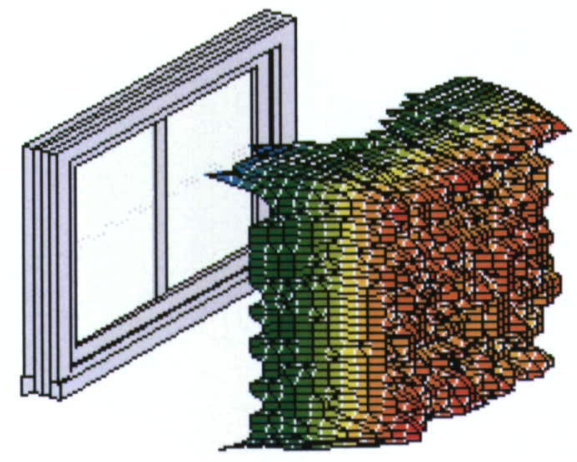

$1.6 \mathrm{kHz}$ 帯域

ロ絵 6 アルミサッシ空からの音響透過を音響インテンシティ法 (固定点法) で計測し, 可視化した例. $500 \mathrm{~Hz}$ 帯域では, サッシの可動部分からの音の透過が顕著である. 一方 $1.6 \mathrm{kHz}$ 帯域はガラス のコインシデンス周波数を含むので, ガラス面全面からの音の透過が卓越している. このよう な可視化結果によれば遮音上の弱点を明瞭に把握することができる.

(東京大学生産技術研究所 坂本 慎一, 千葉工業大学工学部 佐藤 史明, 千葉工業大学情報工学部 矢野博夫, 橘 秀樹) 